$16^{\text {th }}$ International Conference on

AEROSPACE SCIENCES \& AVIATION TECHNOLOGY,

ASAT - 16 - May 26 - 28, 2015, E-Mail: asat@ mtc.edu.eg Military Technical College, Kobry Elkobbah, Cairo, Egypt

Tel : +(202) 24025292-24036138, Fax: +(202) 22621908

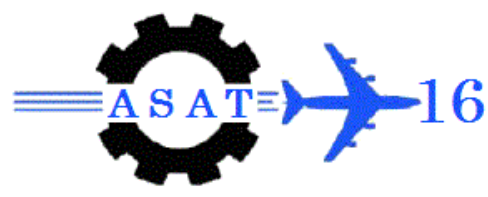

\title{
Kinetics of Ethanol Electrooxidation at a Modified Platinum Electrode in 0.1M Perchloric acid
}

\author{
Y. Atef*, S. Abd El Wanees ${ }^{\dagger}$ and M. M. Hefny ${ }^{\ddagger}$
}

\begin{abstract}
The present paper reports cyclic voltammetry (CV) studies on electrooxidation of ethanol at a modified $\mathrm{Pt}$ electrode surface in $0.1 \mathrm{M}$ perchloric acid solution. The activity of $\mathrm{Pt}$ electrode towards ethanol oxidation increases with increasing number of cycles and concentration of ethanol. Cyclic voltammetry was also used to investigate the electrochemical and thermochemical parameters related to electrooxidation of ethanol under the influence of temperature. The effect of temperature was carried out for a temperature range of 283-303 K. Apparent activation energies of the oxidation reactions on a modified Pt electrode were determined. The enhancement is discussed and attributed to the mechanism of oxidation that is likely to be dissociative chemisorptions involving electron transfer. Kinetic and thermodynamic parameters values for the electrooxidation process $E_{a}{ }^{*}, \Delta G^{*}, \Delta H^{*}$ and $\Delta S^{*}$ have been computed and discussed. The high activation energy for the process suggests that $\mathrm{C}-\mathrm{C}$ bond cleavage is the rate determining step.
\end{abstract}

Keywords: Ethanol electrooxidation, modified Pt electrode

\footnotetext{
* Author for correspondence. Chemistry Administration, Cairo, Egypt.

Address: jasy9@yahoo.com

${ }^{\dagger}$ Chemistry Department, Faculty of Science, Zagazig University, Zagazig, Egypt

$\$$ Chemistry Department, Faculty of Science, Cairo University, Giza, Egypt
} 


\section{Introduction}

In various applications, fuel cells are widely recognized as very attractive devices to obtain directly electric energy from the electrooxidation of a chemical product. The main focus of research in the case of direct alcohol fuel cells is development of novel anodic catalysts, which are mostly platinum [1]. The direct oxidation of methanol in fuel cells has been widely investigated. However, the question of the toxicity of methanol remains crucial. Methanol is considered since a long time as a toxic product, in addition to possible environmental problems in relation to its large miscibility to water. The interest in ethanol has increased, not only as a renewable resource, but especially as a fuel source due to its high theoretical yield of 12 protons and 12 electrons released upon oxidation. Ethanol offers an attractive alternative as a fuel in low temperature fuel cells because it can be produced in large quantities from agricultural products and it is the major renewable biofuel from the fermentation of biomass, while DEFCs are operated at elevated temperatures under enforced electrolyte transport, using high surface area electrodes. The DEFC transforms directly the Gibbs energy of combustion of ethanol into electricity, without a fuel processor. This greatly simplifies the system, reducing its volume and cost $[2,3]$. Wang et al., [4] found that ethanol is a promising alternative fuel with an electrochemical activity comparable to that of methanol. These reasons motivate investigations on ethanol electrooxidation in order to improve the electrical performances when using it in DEFCs, and to open the possibility of replacing methanol indirect alcohol fuel cells. Much effort has been focused on the mechanistic aspects of this reaction on different electrodes materials [5]. Pt is the most active electrode for this reaction [].

Several studies on the electrooxidation of ethanol have been devoted mainly to identifying the adsorbed intermediates on the electrode and elucidating the reaction mechanism by means of various techniques, as differential electrochemical mass spectrometry (DEMS) [ $\underline{7}, 8]$, in situ Fourier transform infrared spectroscopy (FTIRS) [8,9], electrochemical thermal desorption mass spectroscopy (ECTDMS) [10] and SNIFTIRS study [11].

The effect of concentration and temperature are important parameters in electrooxidation of ethanol. The temperature rising operation is an effective method to obtain a high power DEFC. In the case when one measures the electrochemical oxidation of alcohols in aqueous media, the measuring temperature is limited to 60-70 ${ }^{\circ} \mathrm{C}$ which is attributed to the vaporization of the alcohols. In the present study, the electrooxidation properties were investigated using a sheet as the Pt electrode by varying the temperature of the electrolytic solution. In this study, an experimental system of cyclic voltammetry (CV) was used to provide kinetic data of the electrooxidation of ethanol on the Pt electrode in the temperature range of 10 to $30^{\circ} \mathrm{C}$. Based on $\mathrm{CV}$ data, the kinetic parameters and apparent activation energy were evaluated. Additionally, the reaction pathway of ethanol oxidation ( $\mathrm{C} 1 \& \mathrm{C} 2)$ is proposed and discussed in this study.

We have focused on a CV study of ethanol in acidic $\left(0.1 \mathrm{M} \mathrm{HClO}_{4}\right)$ medium on a Pt electrode in order to investigate the thermodynamic parameters $\Delta H, \Delta \mathrm{G}, \Delta \mathrm{S}$ and $\mathrm{E}_{\mathrm{a}}$ of the electrooxidation reaction. Potentiodynamic cyclic voltametry measurements provide important information on the electrochemical characterization of the intermediate species under study and is a simple method for screening the processes 
occurring in a wide potential range though a constant current or potential electrolysis is used more often for practical purposes.

\section{Experimental}

Voltammetric measurements were conducted in a $50 \mathrm{ml}$ conventional cell in 0.1 $\mathrm{M} \mathrm{HClO}_{4}$ under normal atmosphere and with temperature controller. As WE compartment, pure Pt $\left(0.6 \mathrm{~cm}^{2}\right.$ sheet, Aldrich, thermocouple quality) was used. A saturated calomel electrode (SCE) connected to the electrochemical cell by a Luggin capillary, was used as the reference. The counter electrode was a piece of thin rod of platinum of area about $0.3 \mathrm{~cm}^{2}$. All potentials, E, given here are referred to SCE. Solutions were made using high purity (Analar grade) chemicals and triply distilled water. The electrode potential was controlled by a voltage scan generator (VSG 72, Wenking).Before each experiment, the smooth working electrodes were abraded with a fine grade emery paper followed by washing with triply distilled water to clean. The electrode was coated with hydrated $\mathrm{Pt}$ oxide and by the repetitive cycling at a sweep rate of $2000 \mathrm{mV} / \mathrm{still}$ a specified number of cycles $(\mathrm{N})$ in pure $0.1 \mathrm{M} \mathrm{HClO}_{4}$, at $25^{\circ} \mathrm{C}$. The lower and upper potential limits of the cycle are $-400 \mathrm{mV}$ and $+1500 \mathrm{mV}$ vs. SCE, respectively. The organic reductant is spectroscopically pure grade supplied from Merck.An automatically-controlled electronic Wenking Laboratory Poteniostat (LB 75) was used in this work. DC Voltammograms were recorded using Allen, Model 1000 and $\mathrm{X}-\mathrm{Y}$ recorder. The measurements were performed in a conventional three compartments cell. The working electrode compartment was surrounded by a water jacket, for temperature control. The cell temperature was controlled using an ultrathermostat type Polyscience (USA). Each experiment was carried out in a freshly prepared solution and with a newly polished electrode surface. After the formation of the oxide, the electrolyte was replaced by pure $0.1 \mathrm{M} \mathrm{HClO}_{4}$, and then by the same electrolyte but containing ethanol. The cyclic voltammograms were recorded for each solution between the previously specified potential limits at a scan rate of $50 \mathrm{mV} / \mathrm{s}$. The oxidation current density of the reductant, $\mathrm{j}$, was measured as the difference in the anodic current densities for the first cycle in the presence of the reductant and in its absence (pure $0.1 \mathrm{M} \mathrm{HClO}_{4}$ ) at a specified potential of the current plateau. The current densities are referred to the geometric area.

\section{Results and discussion}

\subsection{Cyclic voltammetry}

The surface of $\mathrm{Pt}$ electrode was modified by applying the repetitive cyclizationin $0.1 \mathrm{M} \mathrm{HClO}_{4}$ and it occurs over wider potential region and high scan rate to introduce O-species as the active site on Pt electrode. These active sites improve the catalytic activity of $\mathrm{Pt}$ towards alcohol electrooxidation. The time dependent polarization curves in $\mathrm{HClO}_{4}$ were measured at $15,30,45 \& 60$ minutes of $\mathrm{Pt}$ modification and the roles of the reaction intermediates and the dynamic equilibrium coverage of $\mathrm{Pt}-\mathrm{OH}$ in determining the quasi-stable kinetic current of ORR were also demonstrated. The hydrogen adsorption/desorption region and the oxide formation region also did not show significant variations. But it is important to note an increase in the oxide formation charge as the cyclization time increases. In addition, is observed in the cathodic scan that the oxide reduction peak becomes sharper. 
The cyclic voltammetry of Pt electrode in Figure 1 was performed in $0.1 \mathrm{M}$ $\mathrm{HClO}_{4}$ solution between -0.4 and $1.5 \mathrm{~V}$ at a scan rate of $2000 \mathrm{mVs}^{-1}$ shows the well known adsorption/desorption of weakly and strongly adsorbed $\mathrm{H}$ atoms (peaks Ia, IIa, IIIc) at low potentials and finally the oxide region where the formation of monolayer oxide (IIa). The oxide formation on platinum has been proposed as equations (1) and (2), even though minor processes can take place [12].

$\mathrm{Pt}+\mathrm{H}_{2} \mathrm{O} \rightarrow \mathrm{PtOH}+\mathrm{H}^{+}+\mathrm{e}^{-}$

$\mathrm{PtOH} \rightarrow \mathrm{PtO}+\mathrm{H}^{+}+\mathrm{e}^{-}$

In Figure 1, the oxide reduction normally appears as a single cathodic peak (IIIc) but the reaction is not so simple and may occur in two overlapping steps $[\underline{13}, \underline{14}]$.

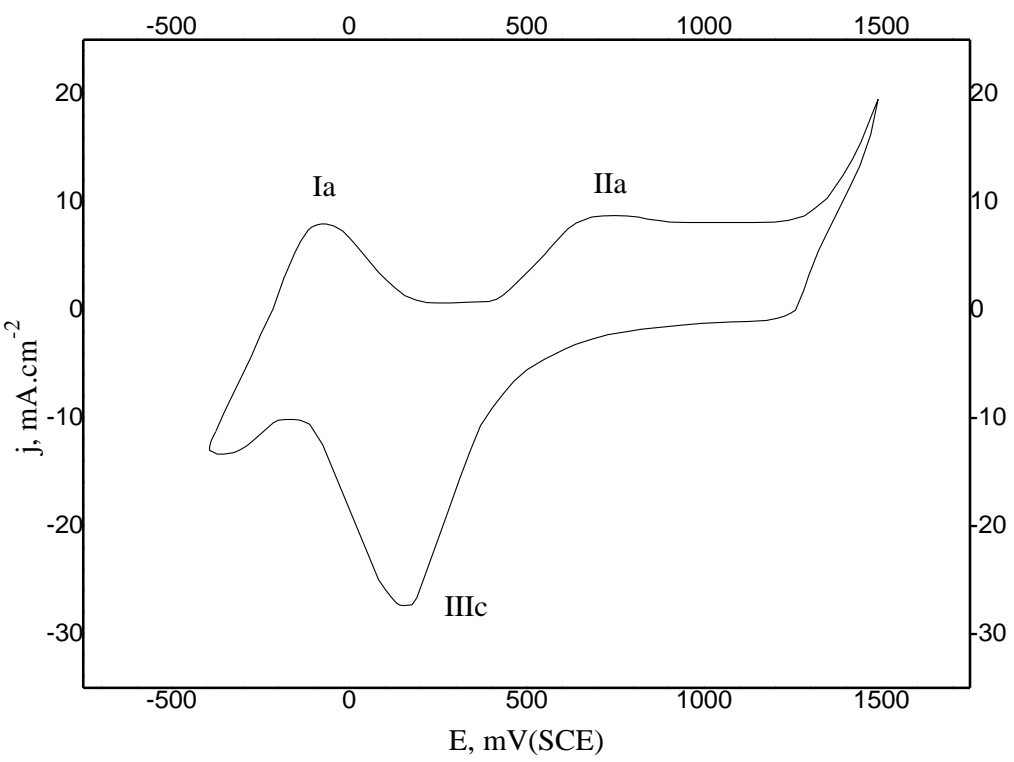

Fig. 1. Cyclic voltammogram of Pt electrode in $0.1 \mathrm{M} \mathrm{HClO}_{4}$ at $2000 \mathrm{mV} \mathrm{s}^{-1}$, after 30 minutes cyclization, at $25{ }^{\circ} \mathrm{C}$.

\subsection{Effect of ethanol concentration}

After the cyclization process of formation the oxide on Pt electrode as an active area of investigation, the performance of the ethanol electrooxidation can be carried out at low scan rate. The cyclic voltammograms of a modified Pt electrode in $0.1 \mathrm{M}$ $\mathrm{HClO}_{4}$ solution between -0.4 and $1.5 \mathrm{~V}$ at a scan rate of $50 \mathrm{mV} \mathrm{s}^{-1}$, in absence and presence of ethanol after 30 minutes of Pt modification are shown in figure 2. It can see clearly that a modified Pt electrode has good electrocatalytic activity for ethanol oxidation. 


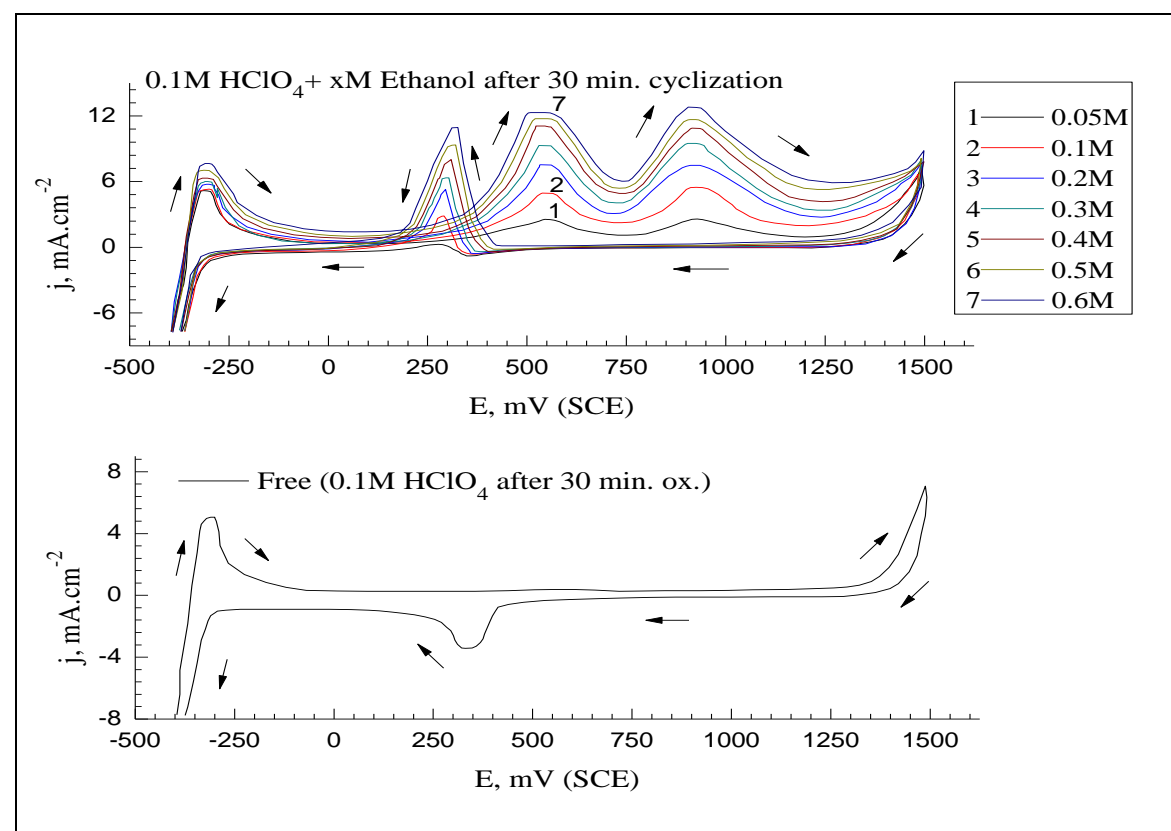

Fig. 2. Cyclic voltammograms of platinum at different concentrations of ethanol, at $25{ }^{\circ} \mathrm{C}$ (30 min. modification), at a sweep rate of $50 \mathrm{mV} / \mathrm{s}$ in $0.1 \mathrm{M} \mathrm{HClO} 4$.

In oxidation of ethanol using platinum electrode in $\mathrm{HClO}_{4}$, there are three peaks which are also designate oxidation of water and ethanol [15]. First peak is residing at the potential about 500-600 while for the second peak it is residing at bigger potential, 900-1000 $\mathrm{mV}$. It shows that peaks which are equal to $\mathrm{CV}$ of ethanol at acid medium occurred at a potential around $500-1000 \mathrm{mV}$. The third peak is observed at lower potential about $300-400 \mathrm{mV}$ and only during the positive-going scan, none being observed in the negative-going scan, evidencing that the $\mathrm{C}-\mathrm{C}$ bond breaking takes place only at lower potentials indicating that $\mathrm{CO}_{2}$ formation [16].

To compare the electrochemical activity of the modified Pt electrode in absence and presence of ethanol, the large current in the anodic region is observed on the modified Pt electrode, which is ascribed to the good activity for ethanol oxidation, which is due to the oxidation of $\mathrm{CO}_{\text {ads }}$ with the $\mathrm{OH}_{\text {ads }}$ on modified Pt sites. It is known that, oxidation of alcohol on a $\mathrm{Pt}$ occurs due to the presence of oxygenated species $(\mathrm{PtO}$ or $\mathrm{PtOH})$, which help the oxidation of $\mathrm{CO}$ to $\mathrm{CO}_{2}$ [17]. The modifier, when added to platinum, improve the catalytic effect of the electrode during the alcohol electrooxidation through the transfer of their oxygenated adsorbed species $(\mathrm{OH}, \mathrm{O}$ or $\mathrm{H}_{2} \mathrm{O}$ ) to neighboring adsorbed organic molecules, at lower potentials than on nonmodified platinum electrode [18].Therefore the objective of research on bimetallic catalysts is to find a metal that can adsorb the $\mathrm{OH}$ radical or any other oxygen containing species at relatively lower potentials [19]. $\mathrm{Pt}-\mathrm{OH}$ reacts with organic poison. Also, the enhancement may occur by preventing the formation of a strongly adsorbed poisoning species such as $\mathrm{CO}$ either by blocking the sites necessary for its adsorption [20] or by oxidizing completely $\mathrm{CO}$ in solution into $\mathrm{CO}_{2}$ [21]. Schell [22] and Krausa and Vielstich [23] have postulated that chemisorbed $\mathrm{CO}$ reacts with weakly bound water and/or chemisorbed $\mathrm{OH}$ to give $\mathrm{CO}_{2}$ [24]. Moreover, the peak potential is less positively shifted and peak current increases by increasing of ethanol concentration.

Plots of the logarithm of current densities $\left(\log \mathrm{j}_{\mathrm{p}}\right)$ vs. the logarithm of the concentrations of ethanol for both anodic and reverse anodic peaks on the modified $\mathrm{Pt}$ electrode as shown in figure (3), in $0.1 \mathrm{M} \mathrm{HClO}_{4}$ after 30 minutes of modification, at 
$25^{\circ} \mathrm{C}$. The increase of the anodic currents does not follow a linear law. This can be explained by saturation of the electrode surface for concentrated ethanol solutions [25], except for the lower ethanol concentration and the slope represents the overall reaction order, $\mathrm{m}$. Thus, for peak $\mathrm{I}_{\mathrm{a}}, \mathrm{m}=0.75$, for peak $\mathrm{II}_{\mathrm{a}}, \mathrm{m}=0.66$ and for peak $\mathrm{III}_{\mathrm{a}}$, $\mathrm{m}=1.8$. In a first approximation, the reaction seems to be controlled by a first-order process during the two oxidation peaks $\mathrm{I}_{\mathrm{a}}, \mathrm{II}_{\mathrm{a}}$ and a second-order process during peak $\mathrm{III}_{\mathrm{a}}$. Therefore, the overall reaction rate is mainly adsorption controlled, and the anodic current can be expressed as:

$\mathrm{I}=\mathrm{n} \mathrm{F} \mathrm{k} \mathrm{C}$

where, $\mathrm{n}$ is the number of electrons, $\mathrm{F}$ the Faraday constant, $\mathrm{k}$ is the rate constant, $\mathrm{C}$ the bulk concentration of the reactant and $\mathrm{m}$ the overall reaction order.

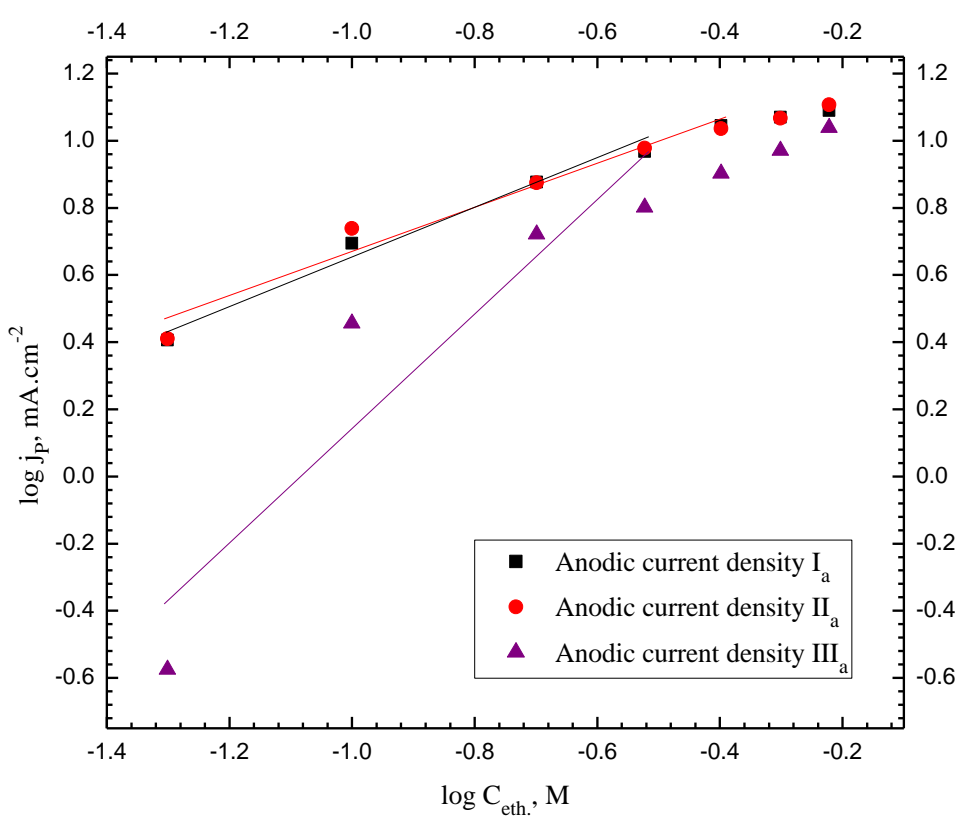

Fig. 3.Plots of $\log j_{p}$ vs. $\log C_{\text {ethanol }}$ for peaks $\mathrm{I}_{\mathrm{a}}, \mathrm{II}_{\mathrm{a}} \& \mathrm{III}_{\mathrm{a}}$ on the modified Pt electrode in $0.1 \mathrm{M} \mathrm{HClO}{ }_{4}\left(30\right.$ minutes of modification), at $25{ }^{\circ} \mathrm{C}$.

\section{Mechanism of ethanol oxidation}

Based on the foregoing work, the global oxidation mechanism of ethanol in acid solution may be summarized in the following scheme of parallel reactions [26]:

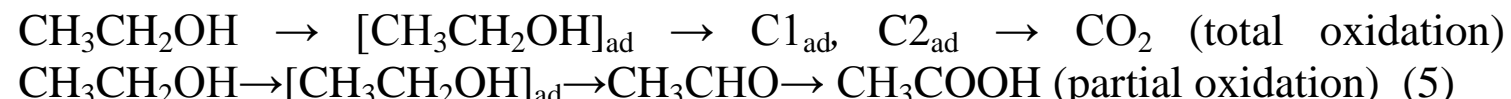

The formation of $\mathrm{CO}_{2}$ goes through two adsorbed intermediates $\mathrm{C}_{\mathrm{ad}}$ and $\mathrm{C} 2$ ad, which represent fragments with one and two carbon atoms, respectively. In spite of many advances in the understanding of the mechanism of ethanol oxidation, there are still some unclear aspects. For instance, there is some controversy on whether acetic acid is formed in one step or through the aldehyde. Also, there is no agreement regarding the nature of the adsorbed species. According to some workers, the carboncarbon bond is preserved, so a larger quantity of intermediates of the type C2 are formed [27,28], but others claim that the main intermediates contain only one carbon atom and are of the type C1 [29,30]. In fact, chemical adsorption of ethanol in the "hydrogen region" generates strongly adsorbed species, from the breaking of the $\mathrm{C}-\mathrm{C}$ bond, like $\mathrm{CO}$ which is oxidized to $\mathrm{CO}_{2}$ at higher potentials. As expected, $\mathrm{Pt}$ is able to break the $\mathrm{C}-\mathrm{C}$ bond of ethanol but it is unable to oxidize the corresponding adsorbates 
at low potentials leading to the same problems as for methanol [31]. So, the addition of $\mathrm{O}$-adlayer increases the electrode activity because of the presence of activated oxygen species.

The first step of the electrochemical oxidation of ethanol at platinum electrode is the dissociative adsorption of ethanol, either via an $\mathrm{O}$-adsorption or a $\mathrm{C}$-adsorption process $[32,33]$, to form acetaldehyde (AAL) according to the following reaction equations. Indeed, it was shown by Hitmi et al., [25] that AAL was formed at potentials lower than $0.6 \mathrm{~V}$. Thus:

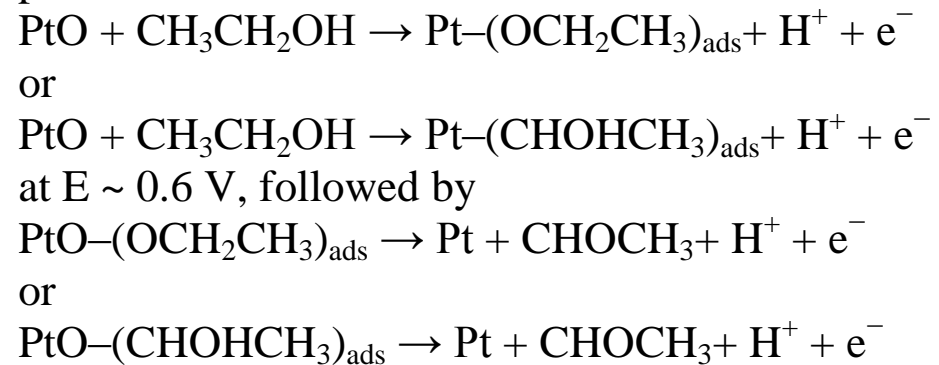

AAL has to be readsorbed for further oxidation either into acetic acid or carbon dioxide. To complete the oxidation reaction leading to both of these species, an extra oxygen atom is needed, which has to be brought by activated (adsorbed) water molecules at the platinum surface. In this study, the supply of these activated sites is more feasible on hydrated oxide surface.

Thus, as soon as AAL is formed, it can adsorb on platinum sites leading to a $\mathrm{PtO}-\mathrm{COCH}_{3}$ species at $\mathrm{E} \sim 0.6 \mathrm{~V}$ :

$\mathrm{PtO}+\mathrm{CHOCH}_{3} \rightarrow \mathrm{PtO}-\left(\mathrm{COCH}_{3}\right)_{\mathrm{ads}}+\mathrm{H}^{+}+\mathrm{e}^{-}(10)$

Further oxidation, without breaking of the $-\mathrm{C}-\mathrm{C}-$ bond, may occur at potentials $>0.9 \mathrm{~V}$, through the activation of water molecules at platinum sites:

$\mathrm{Pt}+\mathrm{H}_{2} \mathrm{O} \rightarrow \mathrm{Pt}-(\mathrm{OH})_{\mathrm{ads}}+\mathrm{H}^{+}+\mathrm{e}^{-} \quad$ at $\mathrm{E}>0.9 \mathrm{~V}$

$\mathrm{PtO}-\left(\mathrm{COCH}_{3}\right)_{\text {ads }}+\mathrm{Pt}-(\mathrm{OH})_{\text {ads }} \rightarrow 2 \mathrm{Pt}+\mathrm{CH}_{3} \mathrm{COOH}$

At potentials higher than $0.6 \mathrm{~V}$, the dissociative adsorption of water occurs on platinum, providing $-\mathrm{OH}$ adsorbed species, able to oxidize further the adsorption residues of ethanol. Then, oxidation of adsorbed $\mathrm{CO}$ species occurs as was shown by FTIR reflectance spectroscopy and $\mathrm{CO}$ stripping experiments [34]:

$\mathrm{Pt}-(\mathrm{CO})_{\mathrm{ads}}+\mathrm{Pt}-(\mathrm{OH})_{\mathrm{ads}} \rightarrow 2 \mathrm{Pt}+\mathrm{CO}_{2}+\mathrm{H}^{+}+\mathrm{e}^{-}$

AAL can also be oxidized, leading to acetic acid (AA), as follows:

$\mathrm{Pt}-\left(\mathrm{CHOCH}_{3}\right)_{\mathrm{ads}}+\mathrm{Pt}-(\mathrm{OH})_{\mathrm{ads}} \rightarrow 2 \mathrm{Pt}+\mathrm{CH}_{3} \mathrm{COOH}+\mathrm{H}^{+}+\mathrm{e}^{-}$

\subsection{Effect of temperature on ethanol oxidation}

Cyclic voltammograms are obtained in $0.1 \mathrm{M} \mathrm{HClO}_{4}+\mathrm{xM}$ ethanol, Figs. (2, 4, $5)$ at different temperatures $\left(10-30{ }^{\circ} \mathrm{C}\right)$. It shows stabilized cyclic voltammograms for the ethanol oxidation reaction on a modified Pt electrode with increasing temperature from 283-303 K. It is observed from figures that the oxidation current in the forward sweeps (peak $\mathrm{I}_{\mathrm{a}}, \mathrm{II}_{\mathrm{a}}$ ) rises by a factor of 2.5 on increase of temperature from 283-303 K.Also, the foot of the curve for ethanol oxidation shifts to less positive potentials with temperature. This indicates that the temperature has a positive effect on ethanol oxidation leading to faster reaction kinetics and reduced deactivation of the oxide surface. With increase in temperature, the peak potentials for ethanol oxidation particularly on a modified Pt electrode shift less positively with a broadening of the peak width. This behavior reflects the simultaneous formation of less strongly bonded Pt-oxides at higher temperature along with the ethanol oxidation. The peak broadening for ethanol oxidation on a modified Pt electrode also suggests that the peak currents 
$\left(\mathrm{I}_{\mathrm{a}}\right)$ and $\left(\mathrm{II}_{\mathrm{a}}\right)$ are independent of $\mathrm{OH}$ adsorption [35]. Another effect of temperature on a modified Pt electrode for ethanol oxidation is the almost vertical increase of reverse oxidation peak $\left(\mathrm{III}_{\mathrm{a}}\right)$ which increases with temperature. Since the renewed oxidation peak is related to the reduction of adsorbed $\mathrm{OH}$ species, the vertical increase indicates that the reduction of the adsorbed $\mathrm{OH}$ occurs very fast at high temperatures on Pt.

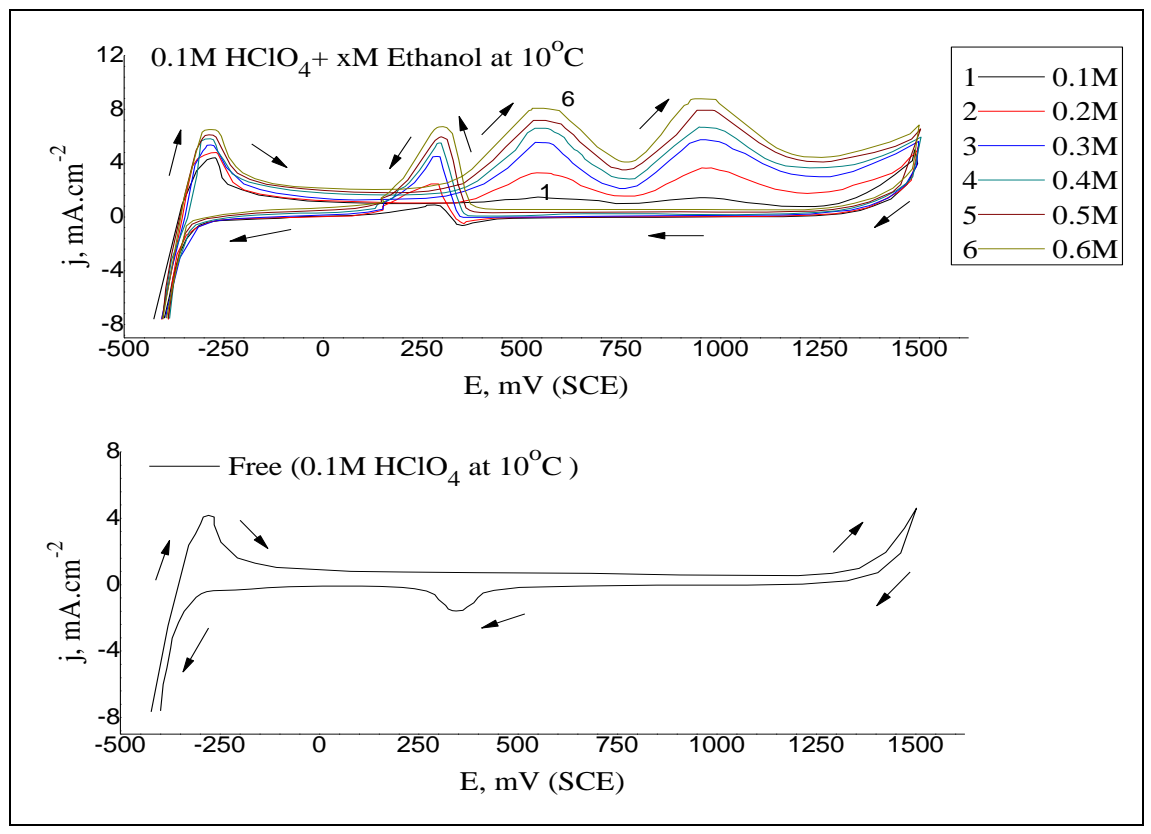

Fig. 4.Cyclic voltammograms of platinum at different concentrations of ethanol, at $10{ }^{\circ} \mathrm{C}$ (30 min. modification), at the sweep rate of $50 \mathrm{mV} / \mathrm{s}$ in $0.1 \mathrm{M} \mathrm{HClO}_{4}$.

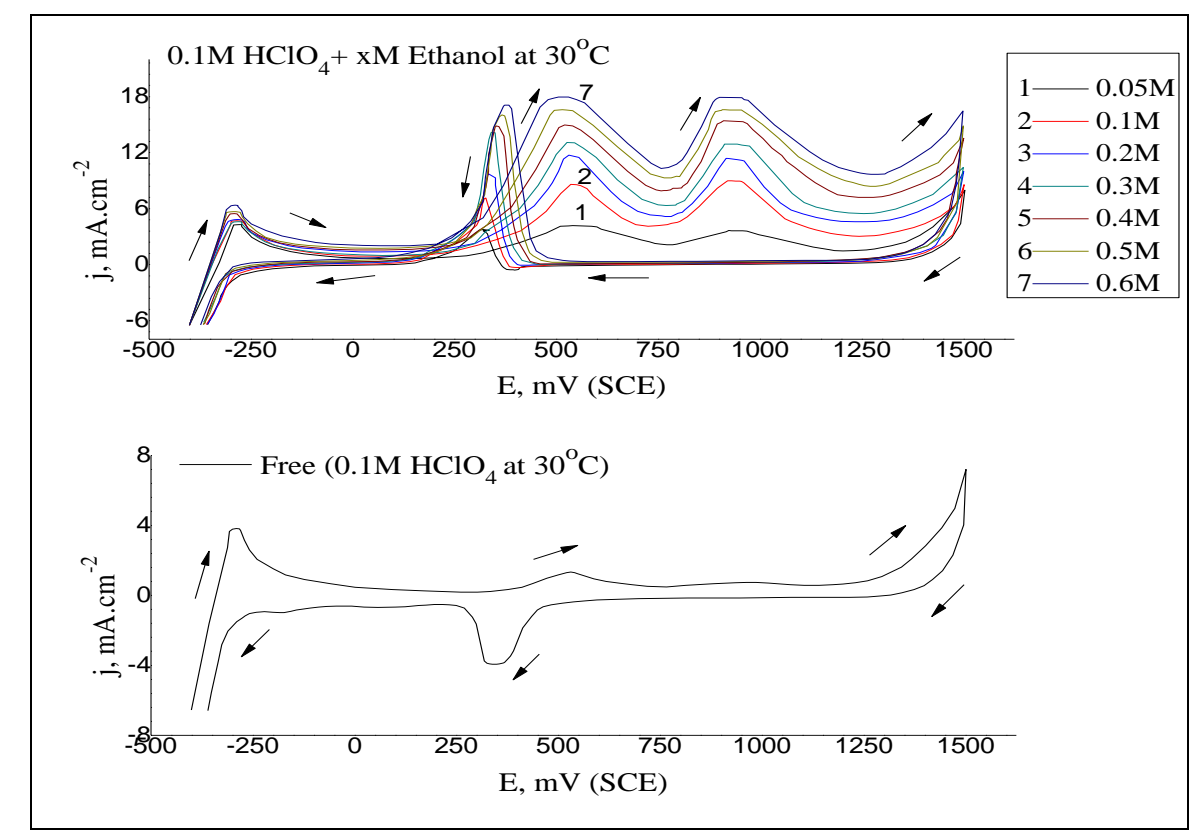

Fig. 5. Cyclic voltammograms of platinum at different concentrations of ethanol, at 30 ${ }^{\circ} \mathrm{C}\left(30 \mathrm{~min}\right.$. modification), at the sweep rate of $50 \mathrm{mV} / \mathrm{s}$ in $0.1 \mathrm{M} \mathrm{HClO}_{4}$.

Lower $\mathrm{H}_{2} \mathrm{O}$ binding energy of $\mathrm{Pt}$ could be one of the reasons for this behavior [36]. The forward sweep is characterized by the typical peak current, which declines due to the formation of strongly bonded Pt-oxides/hydroxide as surface species. In the reverse sweep, the progressive reduction of these oxides initiates the renewed oxidation of the ethanolic species at low potentials. With increase in temperature, the 
potential differences between $\mathrm{I}_{\mathrm{a}}$ and $\mathrm{II}_{\mathrm{a}}$ peaks are reduced. Since the peak potential corresponding to $\mathrm{I}_{\mathrm{a}}$ are significantly related to $\mathrm{OH}$ production by $\mathrm{H}_{2} \mathrm{O}$ dissociation, the reduced potential difference suggests that $\mathrm{OH}$ production on $\mathrm{Pt}$ is activated at higher temperature. Variation of anodic current density for peak $\left(\mathrm{I}_{\mathrm{a}}\right)$ with temperature at different ethanol concentration is shown in figure (6).

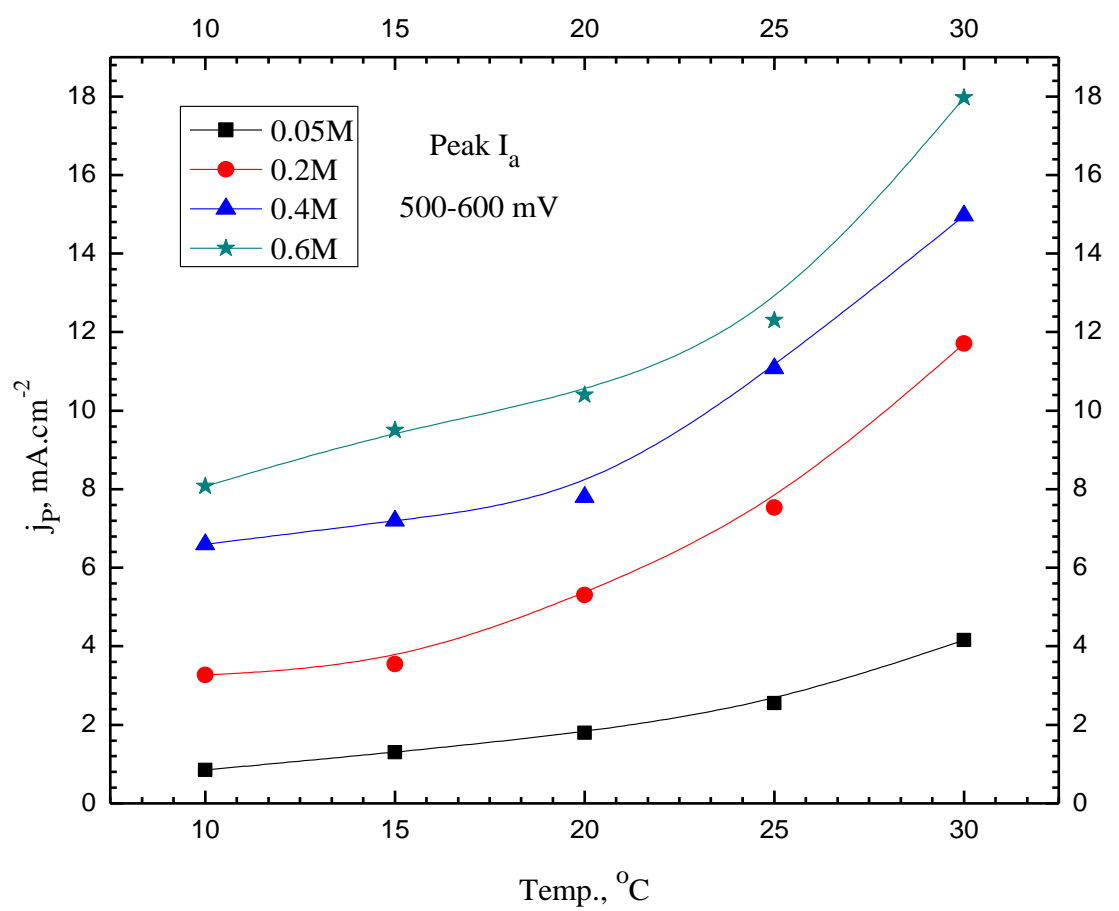

Fig. 6. Variation of anodic current density for peak $\left(I_{a}\right)$, as a function of temperature at different ethanol concentration in $0.1 \mathrm{M} \mathrm{HClO}_{4}$.

To determine activation energy by electrochemical kinetics methods, polarization curves at $50 \mathrm{mV} \mathrm{s}^{-1}$ in $0.1 \mathrm{M} \mathrm{HClO}_{4}+\mathrm{x} \mathrm{M} \mathrm{CH} \mathrm{CH}_{2} \mathrm{OH}$ were obtained, figure (7). The increase in the rate of ethanol oxidation reaction with temperature can be explained as a consequence of the decrease in the $\mathrm{CO}$ adsorption at the surface active sites and shift to less positive potentials in the oxidation of the adsorbed $\mathrm{CO}$. At this potential, the site is rapidly oxidized and the reaction rate increases.

The determination of $\mathrm{E}_{\mathrm{a}}$ *values is carried out by increasing the temperature of the solution and obtaining the current density as a function of temperature at a given potential. The dependence of the oxidation current on temperature can be expressed by the Arrhenius equation: $\mathrm{k}=\mathrm{A}\left[\exp \left(-\mathrm{E}_{\mathrm{a}} * / \mathrm{RT}\right)\right]$; where $\mathrm{k}$ is the reaction rate constant, $\mathrm{A}$ is a constant, $\mathrm{E}_{\mathrm{a}}{ }^{*}$ is the activation energy of the electrooxidation reaction, $\mathrm{T}$ is the temperature in Kelvin, and $\mathrm{R}$ is the universal gas constant. Figure (7) depict the Arrhenius plots, the logarithmic of the oxidation current (log $\mathrm{I}$ ) against the reciprocal of temperature $(1 / \mathrm{T})$ for a modified platinum electrode in $0.1 \mathrm{M} \mathrm{HClO}_{4}$ in the presence of different concentrations of ethanol, for peak $\left(\mathrm{I}_{\mathrm{a}}\right)$. The plots obtained are straight lines. The activation energy, $\mathrm{E}_{\mathrm{a}}{ }^{*}$, was calculated from the slope $[2.303 \mathrm{~d}(\log \mathrm{I}) / \mathrm{d}$ $(1 / \mathrm{T})]$ of each line, table (1). It was found that apparent activation energy in ethanol oxidation at intermediate temperatures ranged from 100.71 to $27.29 \mathrm{~kJ} \mathrm{~mol}^{-1}$ at peak $\mathrm{I}_{\mathrm{a}}$, 84.25 to $25.37 \mathrm{~kJ} \mathrm{~mol}^{-1}$ at peak $\mathrm{II}_{\mathrm{a}}$ and 87.79 to $30.98 \mathrm{~kJ} \mathrm{~mol}^{-1}$ at peak $\mathrm{III}_{\mathrm{a}}$, shown in table (1), which is relatively decreased with increasing the ethanol concentration. It is possible to explain that ethanol electrooxidation occurs via the $\mathrm{C}-\mathrm{C}$ bond breaking pathway and lead to the lower of $\mathrm{E}_{\mathrm{a}}{ }^{*}$ value [37]. In addition, the enthalpy, entropy and 
free energy were computed in electro-oxidation of ethanol and the results are given in table (2).

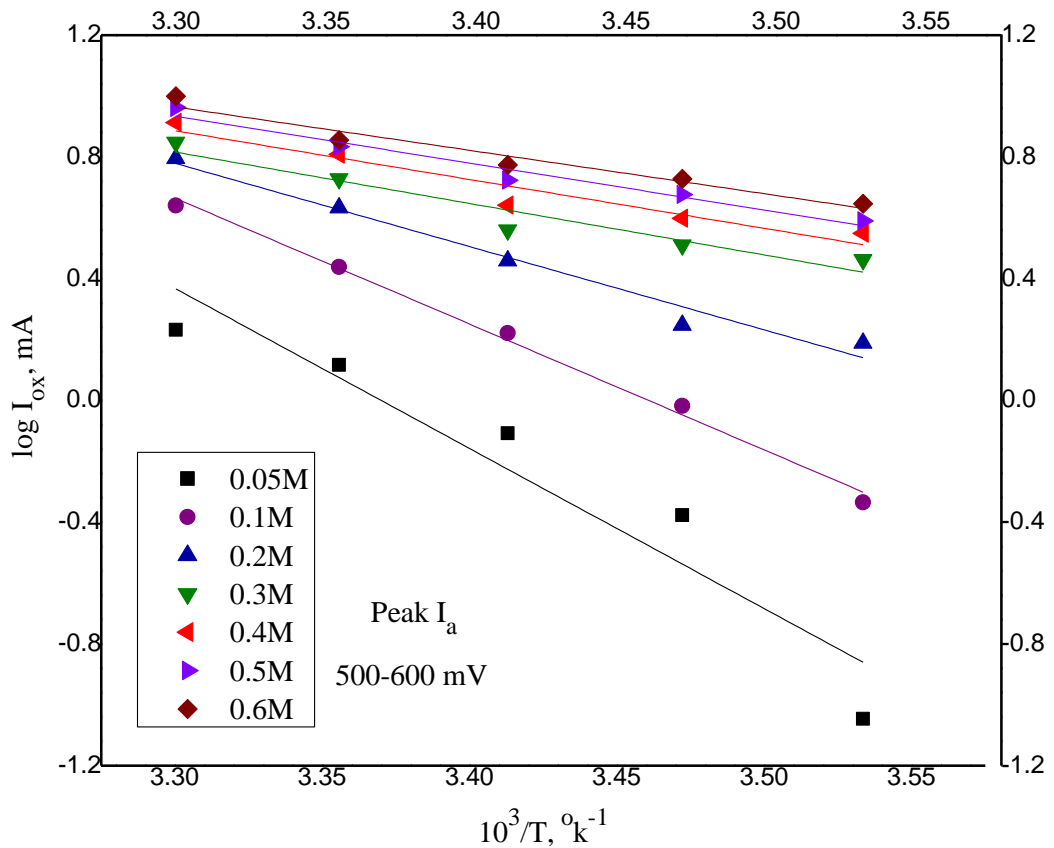

Fig. 7.Arrhenius plot, $\log \mathrm{I}_{\mathrm{ox}}$ against $1 / \mathrm{T}$ for the modified $\mathrm{Pt}$ in $0.1 \mathrm{M} \mathrm{HClO}_{4}$ at different ethanol concentration, for peak $\left(\mathbf{I}_{\mathbf{a}}\right)$.

Table 1. Activation energy, $\mathrm{E}_{\mathrm{a}}$, $\left(\mathrm{kJ} \mathrm{mol}^{-1}\right)$ for oxidation current at different concentrations of ethanol for all anodic peaks $\mathbf{I}_{\mathrm{a}}, \mathrm{II}_{\mathrm{a}} \& \mathrm{III}_{\mathrm{a}}$.

\begin{tabular}{|c|c|c|c|}
\hline \multirow{2}{*}{ Concentration } & \multicolumn{3}{|c|}{$\left.\mathbf{E}_{\mathbf{a}}{ }^{*}, \mathbf{k J ~ m o l}^{\mathbf{1}}\right)$} \\
\cline { 2 - 4 } & $\mathbf{I}_{\mathbf{a}}$ & $\mathbf{I I}_{\mathbf{a}}$ & III $_{\mathbf{a}}$ \\
\hline $0.05 \mathrm{M}$ & 100.71 & 84.25 & 87.79 \\
\hline $0.1 \mathrm{M}$ & 79.15 & 79.6 & 74.39 \\
\hline $0.2 \mathrm{M}$ & 52.39 & 44.75 & 46.68 \\
\hline $0.3 \mathrm{M}$ & 32.36 & 31.2 & 36.04 \\
\hline $0.4 \mathrm{M}$ & 30.7 & 31.2 & 33.07 \\
\hline $0.5 \mathrm{M}$ & 29.55 & 26.79 & 32.88 \\
\hline $0.6 \mathrm{M}$ & 27.29 & 25.37 & 30.98 \\
\hline
\end{tabular}


Table 2. Thermodynamic parameters for oxidation current at different concentrations of ethanol for all anodic peaks $\mathbf{I}_{\mathrm{a}}, \mathrm{II}_{\mathrm{a}} \& \mathrm{III}_{\mathrm{a}}$.

\begin{tabular}{|c|c|c|c|}
\hline $\begin{array}{c}\text { Ethanol } \\
\text { concentration }\end{array}$ & $\begin{array}{c}\Delta \mathbf{H}^{*} \\
\left(\mathbf{k J m o l}^{-1}\right)\end{array}$ & $\begin{array}{c}\Delta \mathbf{S}^{*} \\
\left(\mathrm{Jmol}^{-1} \mathbf{K}^{-1}\right)\end{array}$ & $\begin{array}{c}\Delta \mathbf{G}^{*} \\
\left(\mathrm{kJmol}^{-1}\right)\end{array}$ \\
\hline \multicolumn{4}{|c|}{$\mathbf{I}_{\mathrm{a}}$} \\
\hline $0.05 \mathrm{M}$ & 98.28 & 9.89 & 95.99 \\
\hline $0.1 \mathrm{M}$ & 76.72 & -61.32 & 95 \\
\hline $0.2 \mathrm{M}$ & 49.96 & -153.07 & 95.58 \\
\hline $0.3 \mathrm{M}$ & 29.93 & -221.85 & 96.04 \\
\hline $0.4 \mathrm{M}$ & 28.26 & -228.4 & 96.32 \\
\hline $0.5 \mathrm{M}$ & 27.11 & -233.02 & 96.55 \\
\hline $\bar{~} 0.6 \mathrm{M}$ & 24.85 & -241.51 & 96.82 \\
\hline \multicolumn{4}{|c|}{$\mathbf{I I}_{\mathbf{a}}$} \\
\hline $0.05 \mathrm{M}$ & 81.82 & -50.58 & 96.89 \\
\hline $0.1 \mathrm{M}$ & 77.03 & -64.77 & 96.33 \\
\hline $0.2 \mathrm{M}$ & 42.32 & -184.11 & 97.19 \\
\hline $0.3 \mathrm{M}$ & 28.72 & -231.24 & 97.63 \\
\hline $0.4 \mathrm{M}$ & 28.72 & -232.57 & 98.03 \\
\hline $0.5 \mathrm{M}$ & 24.36 & -247.91 & 98.24 \\
\hline $0.6 \mathrm{M}$ & 22.94 & -253.41 & 98.46 \\
\hline \multicolumn{4}{|c|}{ III $_{\mathrm{a}}$} \\
\hline $0.05 \mathrm{M}$ & 85.36 & -16.86 & 90.38 \\
\hline $0.1 \mathrm{M}$ & 71.94 & -60.19 & 89.88 \\
\hline $0.2 \mathrm{M}$ & 44.25 & -160.05 & 91.95 \\
\hline $0.3 \mathrm{M}$ & 33.6 & -200.09 & 93.23 \\
\hline $0.4 \mathrm{M}$ & 30.64 & -231.71 & 94.33 \\
\hline $0.5 \mathrm{M}$ & 30.44 & -216.78 & 95.04 \\
\hline $0.6 \mathrm{M}$ & 28.55 & -225.22 & 95.67 \\
\hline
\end{tabular}

\subsection{Effect of time of Pt modification}

Fundamental studies of ethanol reactions on metals and oxides, examining the relationships between surface properties (structure, surface defects, etc.) and the reaction yields, have helped to further our understanding of the various processes. The different reactions occurring with ethanol on metal and metal oxide surfaces are showed in previous [38]. The reaction can be shifted from $\mathrm{CO}$ to $\mathrm{CO}_{2}$ and from $\mathrm{H}_{2}$ to $\mathrm{H}_{2} \mathrm{O}$, depending on the ethanol: oxygen ratio. Thus, the balance is not simple and the role of the catalyst is crucial.

Dissociative chemisorption of the alcohols is a process which occurs at fairly high potentials, at which the Pt surface contains oxide or hydroxide sites, and, in principle, the reactivity of the hydroxyl group of the alcohol should be independent of the chain length [39]. For most electrocatalytic processes the specific activity (i.e. the activity per unit hydrogen electrode area) of platinized platinum $(\mathrm{Pt} / \mathrm{Pt})$ electrodes is lower than that of smooth $\mathrm{Pt}$ [40].

The cyclic voltammetry of a modified Pt electrode was also performed in $0.1 \mathrm{M}$ $\mathrm{HClO}_{4}$ solution between -0.4 and $1.5 \mathrm{~V}$ at a scan rate of $50 \mathrm{mV} \mathrm{s}{ }^{-1}$ after modification 
of Pt electrode for 15, 30, 45, 60 minutes, as shown in figures $(8,2,9,10)$, respectively. From these figures, we can see clearly that the modification increases the electrocatalytic activity for ethanol oxidation by increasing number and activity of the reaction sites.

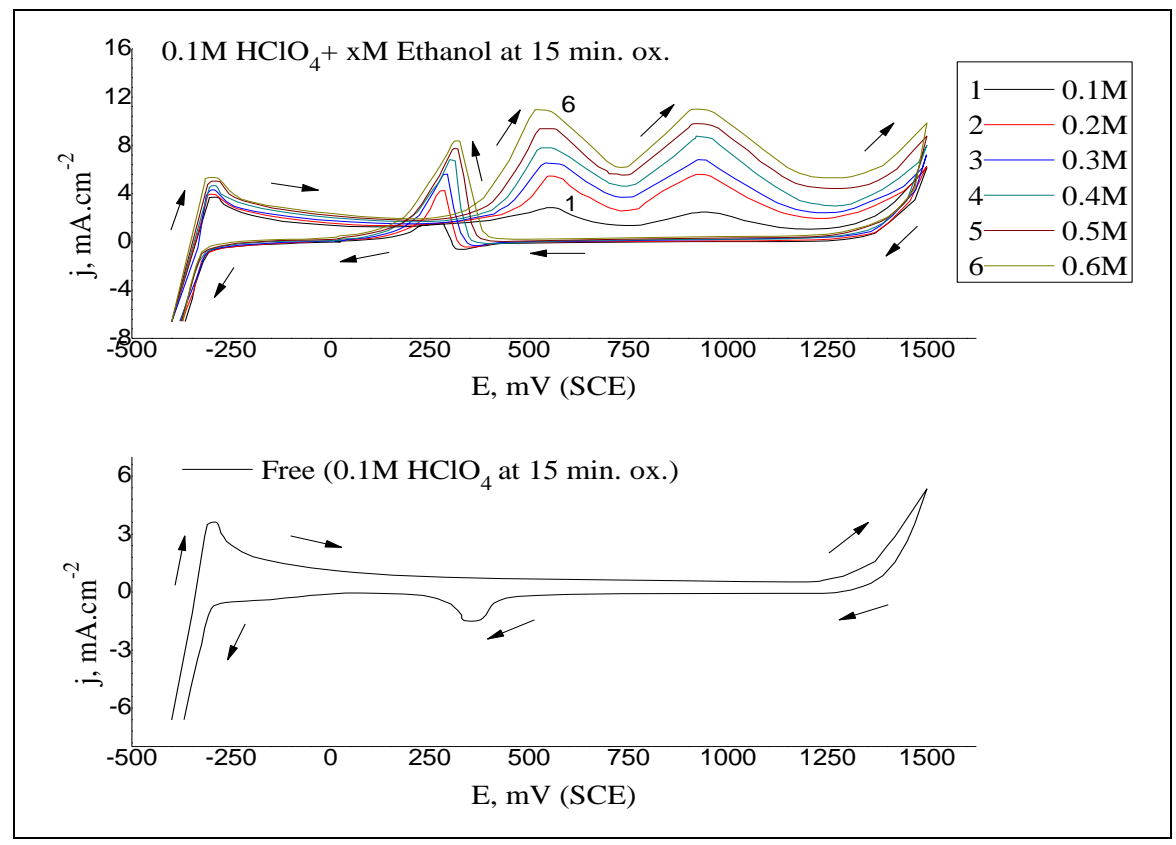

Fig. 8. Cyclic voltammograms of platinum at different concentrations of ethanol, at 25 ${ }^{\circ} \mathrm{C}\left(15 \mathrm{~min}\right.$. modification), at the sweep rate of $50 \mathrm{mV} / \mathrm{s}$ in $0.1 \mathrm{M} \mathrm{HClO}_{4}$.

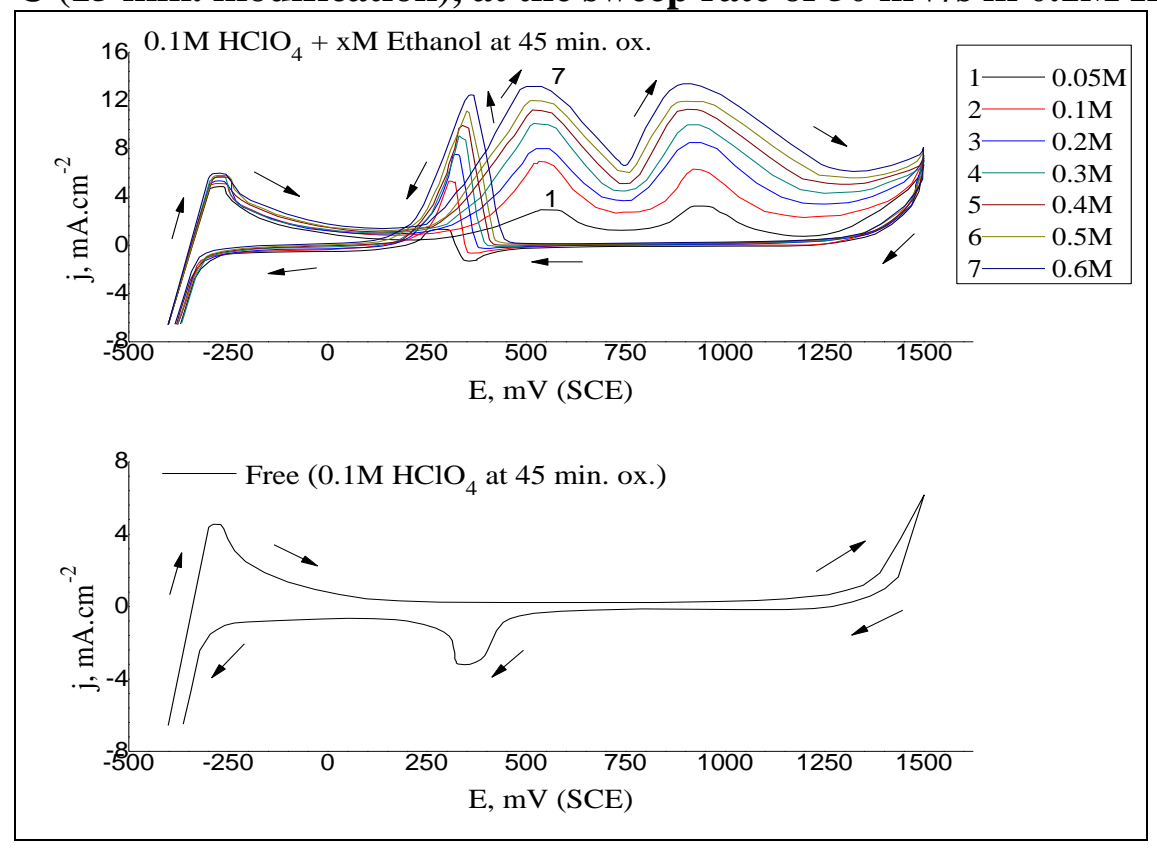

Fig. 9. Cyclic voltammograms of platinum at different concentrations of ethanol, at 25 ${ }^{\circ} \mathrm{C}$ (45 min. modification), at the sweep rate of $50 \mathrm{mV} / \mathrm{s}$ in $0.1 \mathrm{M} \mathrm{HClO}_{4}$. 


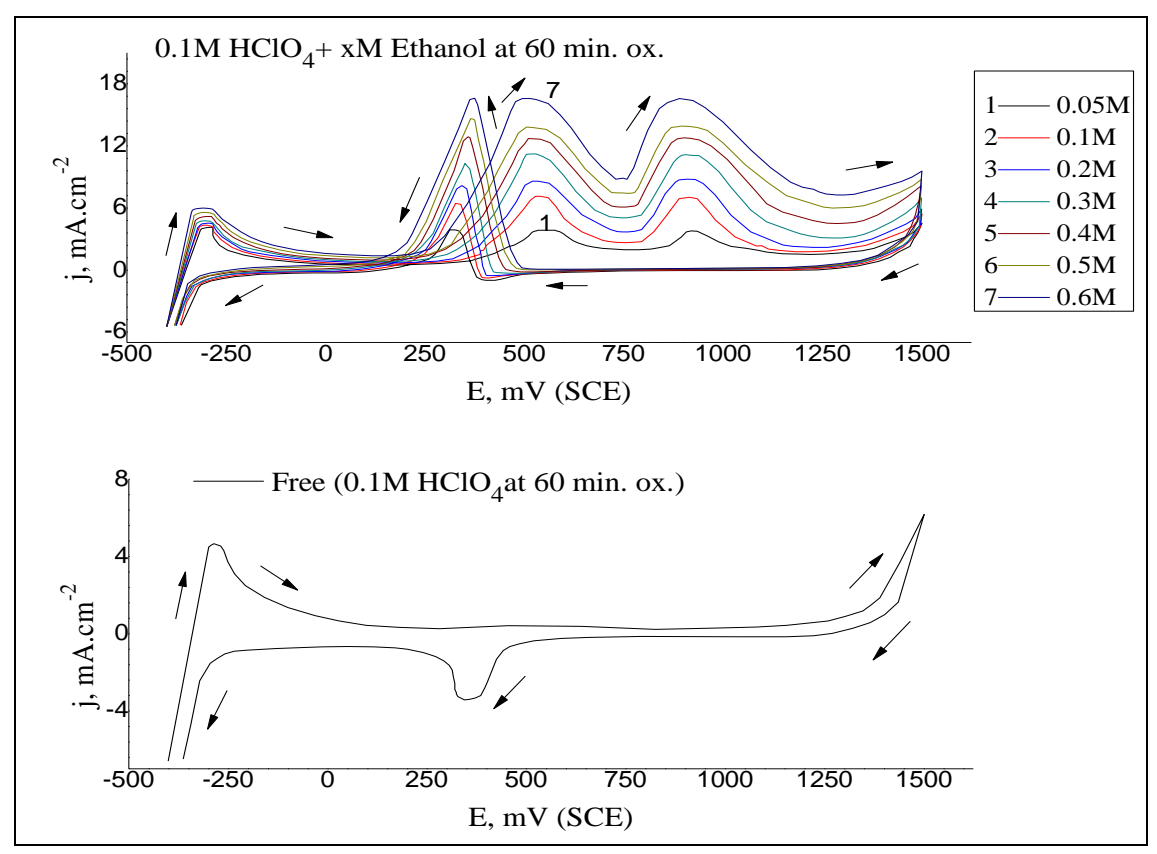

Fig. 10. Cyclic voltammograms of platinum at different concentrations of ethanol, at 25 ${ }^{\circ} \mathrm{C}\left(60 \mathrm{~min}\right.$. modification), at the sweep rate of $50 \mathrm{mV} / \mathrm{s}$ in $0.1 \mathrm{M} \mathrm{HClO}_{4}$.

Plots of the logarithm of current densities $\left(\log \mathrm{j}_{\mathrm{p}}\right)$ vs. the logarithm of the concentrations of ethanol for anodic peak $\left(\mathrm{I}_{\mathrm{a}}\right)$ on the modified Pt electrode in $0.1 \mathrm{M}$ $\mathrm{HClO}_{4}$ after different times of modification, are shown in figure (11) at $25{ }^{\circ} \mathrm{C}$. The rate of current increase is higher for lower number of cycles and decreased gradually due to saturation of the surface by active sites at longer cyclization.

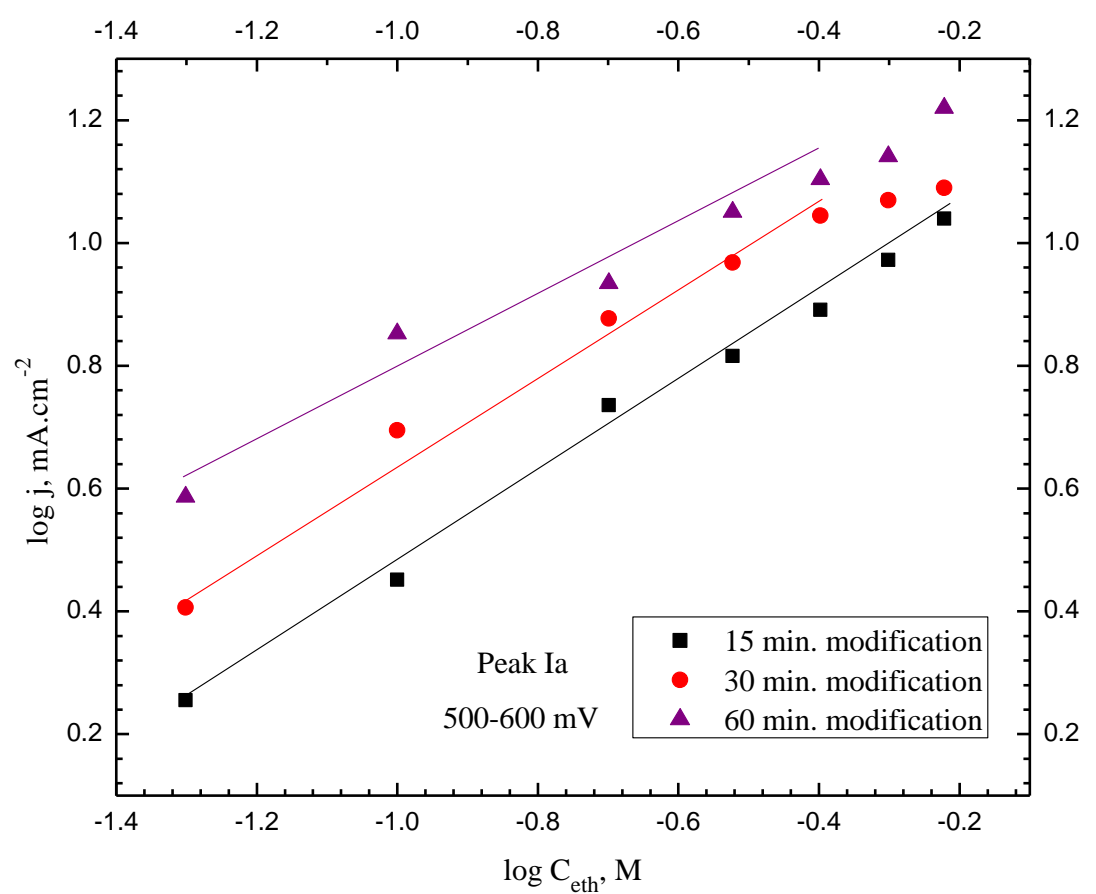

Fig. 11. Plots of $\log j_{p}$ vs. $\log \mathrm{C}_{\text {ethanol }}$ for anodic peak $\left(\mathrm{I}_{\mathrm{a}}\right)$ in $0.1 \mathrm{M} \mathrm{HClO}_{4}$ after different times of modification, at $25{ }^{\circ} \mathrm{C}$.

It can be observed that the CVs exhibit the irreversible nature of the ethanol electrooxidation that is characteristic of the modified Pt catalyst. The onset for ethanol electrooxidation occurs at approximately $0.4 \mathrm{~V}$ but a shift to more negative potentials is 
clearly apparent when introducing $\mathrm{O}$-species on the Pt electrode, especially in the case of the 60 minutes of modification compared to those of $15,30,45$ minutes of modification to reach about $0.3 \mathrm{~V}$. Moreover, different maximum current densities are achieved during the positive potential scan. The highest current density is apparent for 60 minutes modification, and it is about 1.5 that obtained for 15 minutes modification. The modified Pt electrocatalyst also increases the catalytic activity of higher ethanol concentrations, by a factor of 5 when compared to lower ethanol concentrations. Therefore, the activity order towards ethanol electrooxidation can be established as follows: the modification for (60 minutes $>45$ minutes $>30$ minutes $>15$ minutes). Then, the content of oxides/hydroxides on the Pt catalysts affects the catalytic activity for ethanol electrochemical oxidation allowing the oxidation at lower potentials and increasing the current density values.

The electrochemical parameters for the oxidation reaction including the onset potential and the anodic peak potential $\left(\mathrm{E}_{\mathrm{s}}^{\mathrm{Ia}}, \mathrm{E}_{\mathrm{p}}^{\mathrm{Ia}}\right)$, are given in figures $(12,13)$, respectively. The onset potential $\left(\mathrm{E}_{\mathrm{s}}^{\mathrm{Ia}}\right)$ for given concentrations $(0.05-0.6 \mathrm{M})$ after 15 minutes modification decreases from 0.46 to $0.37 \mathrm{~V}$ and decreases about 0.42 to $0.31 \mathrm{~V}$ after 60 minutes modification for the anodic peak $\left(\mathrm{I}_{\mathrm{a}}\right)$. The peak potential $\left(\mathrm{E}_{\mathrm{p}}^{\mathrm{Ia}}\right)$ after 15 minutes modification is $0.55-0.51 \mathrm{~V}$ decreases to $0.53-0.49 \mathrm{~V}$ after 60 minutes modification for the same peak which are approximately close to each other. So, the increase in current peaks $\left(\mathrm{I}_{\mathrm{p}}{ }^{\mathrm{Ia}}\right)$ was noticed by increasing the modification time of $\mathrm{Pt}$ electrode and also by the ethanol concentration.

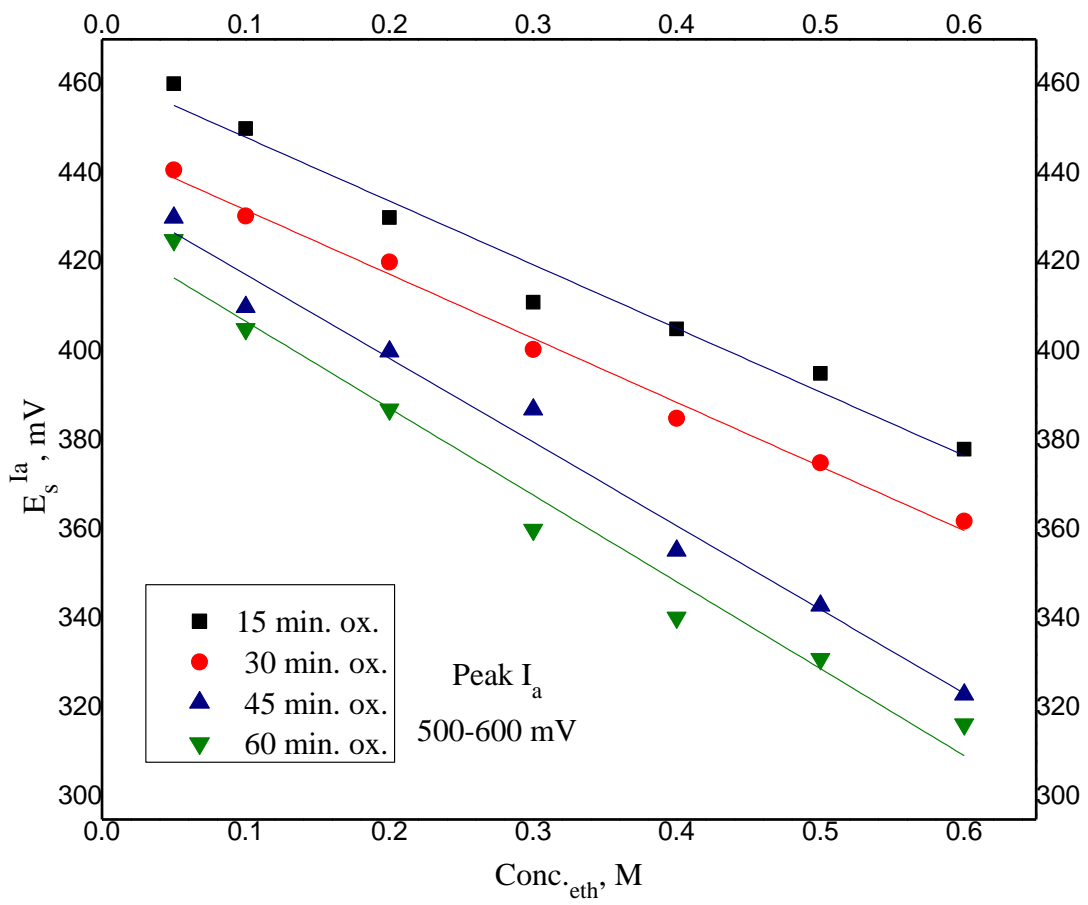

Fig. 12. Variation of onset potential for peak $\left(I_{a}\right)$, as a function of ethanol concentrationin $0.1 \mathrm{M} \mathrm{HClO}_{4}$, at different times of Pt modification. 


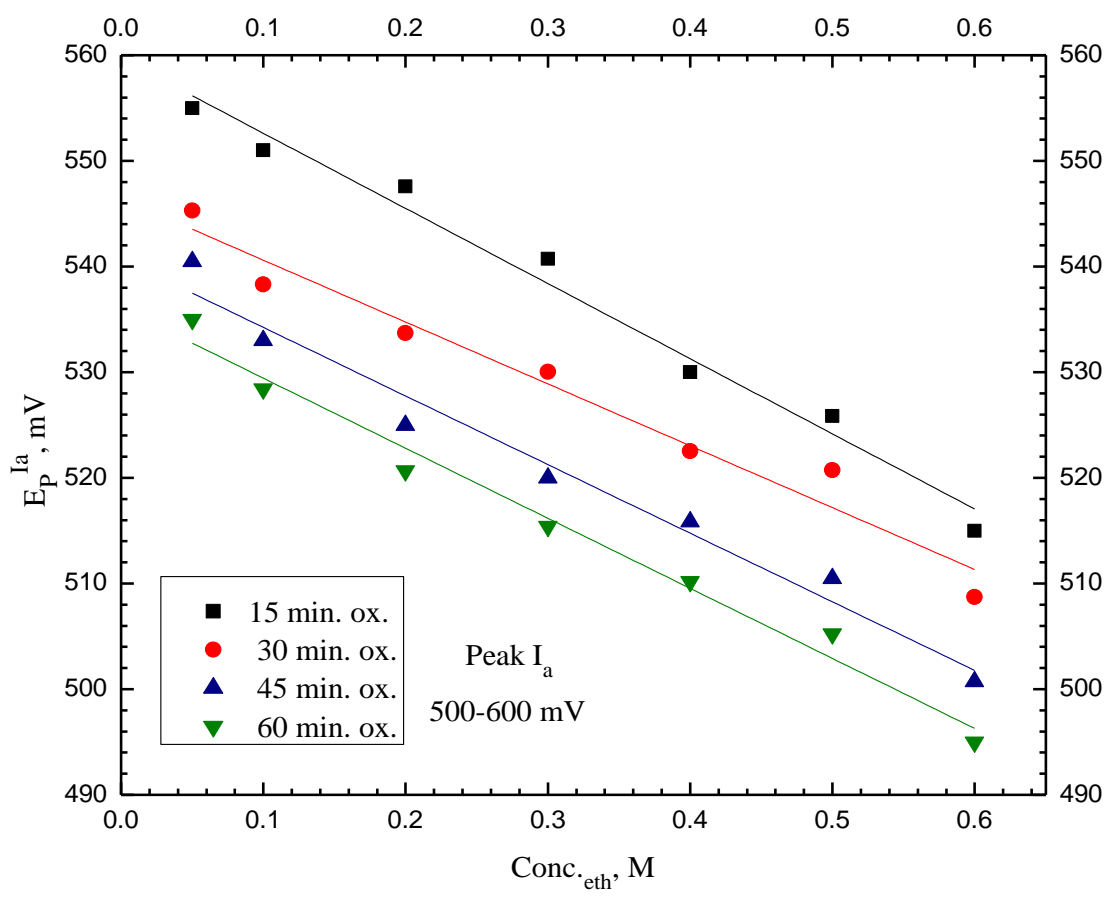

Fig. 13. Variation of peak potential for peak $\left(I_{a}\right)$, as a function of ethanol concentration in $0.1 \mathrm{M} \mathrm{HClO}_{4}$, at different times of $\mathrm{Pt}$ modification.

\subsection{Quantity of Electricity Curves:}

Here, we used the amount of coulombs released during alcohol electrooxidation to measure the activity of ethanol electrooxidation. Charge associated with a cyclic voltammetry could be determined by manual technique of cutting and weighing the peaks and then taking the ratio of the peak weight to a rectangle of a known area and weight [41].

Figure (14) represents the charge density involved in the ethanol electrooxidation in $0.1 \mathrm{M} \mathrm{HClO}_{4}$ solution compartment as a function of different ethanol concentrations after 30 minutes of $\mathrm{Pt}$ modification.

It was found that the quantity of electricity increases as ethanol concentration increases. It can be seen that, in the case of $0.05-0.6 \mathrm{M}$ ethanol and 30 minutes of $\mathrm{Pt}$ modification, the quantity of electricity increased from 52.9 to $243.7 \mathrm{mC} \mathrm{cm}^{-2}$. The results show that ethanol is more easily electrochemically oxidized as ethanol concentration increases. The charging performance of ethanol electrooxidation increases at the modified Pt electrode and higher concentrations of ethanol. 


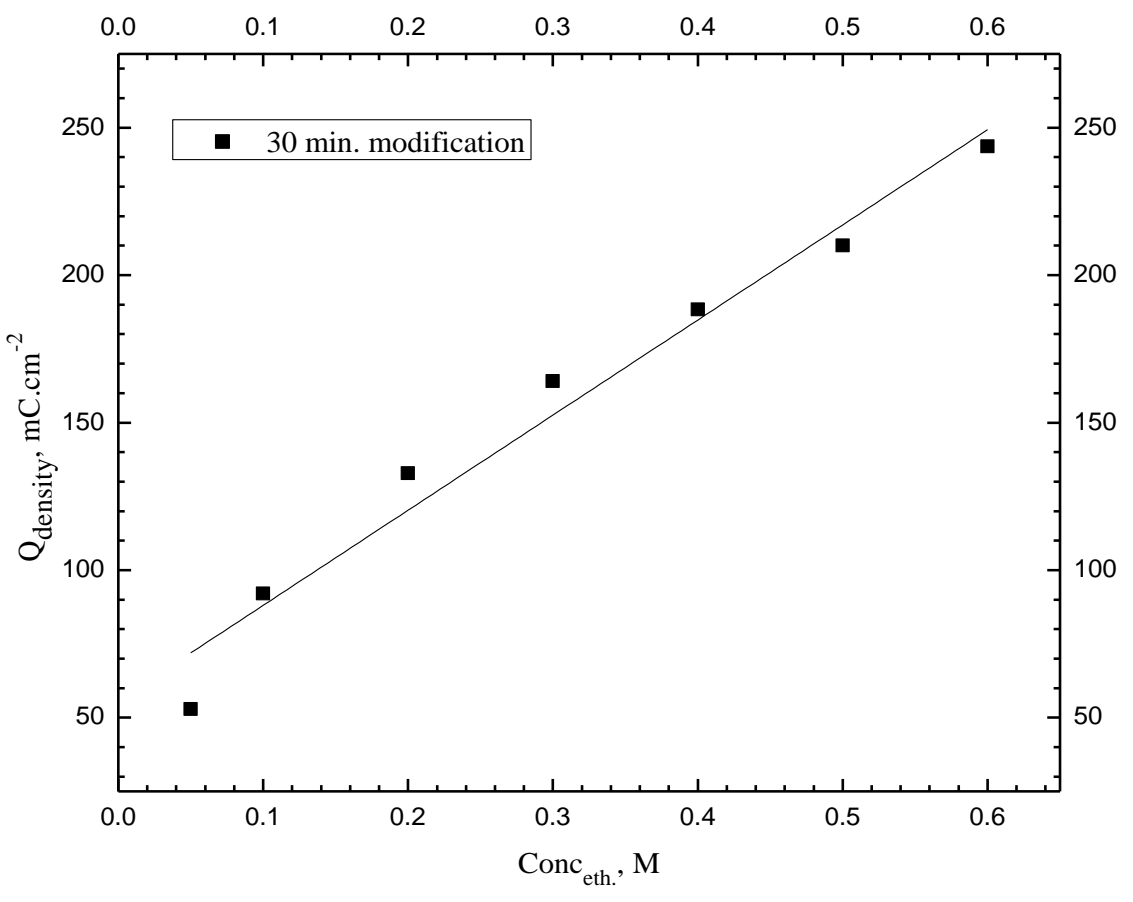

Fig. 14. Quantity of electricity for different ethanol concentrationsin $\mathrm{0.1M} \mathrm{HClO}_{4}$, after 30 minutes of Pt modification.

The charge densities of ethanol electrooxidation were evaluated in the temperature range of $10-30{ }^{\circ} \mathrm{C}$, shown in Fig. (15). The results obtained clearly show on the modified Pt based electrocatalysts, the charge density in case of $30{ }^{\circ} \mathrm{C}$ was $2-3$ times higher than in case of $10{ }^{\circ} \mathrm{C}$, reaching a limiting value of $372.14 \mathrm{mC} \mathrm{cm}^{-2}$. It is clear that the temperature rising has a positive effect on the anode performance towards ethanol oxidation; in addition to the ethanol concentration which improves the extent oxidation of ethanol.

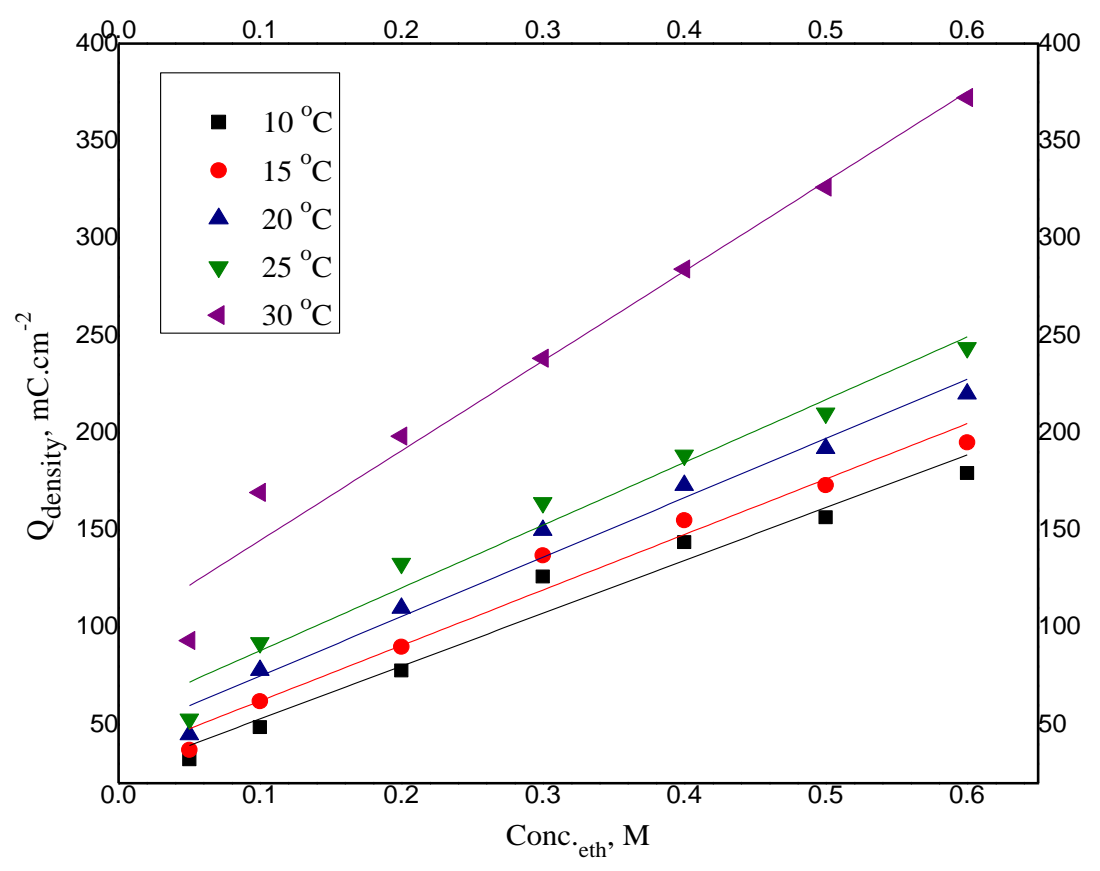

Fig. 15. Quantity of electricity as a function of ethanol concentrationin $0.1 \mathrm{M} \mathrm{HClO}_{4}$, at different temperatures, after 30 minutes of $\mathrm{Pt}$ modification. 
The Effect of modification time for the electrooxidation of ethanol on the modified Pt electrode prepared with different modification time was shown in Fig. (16). When the modification time was prolonged from 15 to 60 minutes, the amount of coulombs for the alcohol oxidation increased with the modification time. The oxide thick film obtained at the modification time of 60 minutes shows a higher catalytic activity than at obtained in the case of modification time of 15 minutes. Therefore, the modification time can strongly affect the electrooxidation process. When the modification time increased from 15 to 60 minutes, the charge density increased from 133.9 to $203.3 \mathrm{mC} \mathrm{cm}^{-2}$ for $0.3 \mathrm{M}$ of ethanol. Meanwhile, the synergistic effect of oxide film and ethanol concentration on the overall catalytic activity of the $\mathrm{Pt}$ electrode can be taken into account. Consequently, for low adsorbed oxide, the modified Pt catalyst exhibits low catalytic activity due to the lack of active oxidizing species.

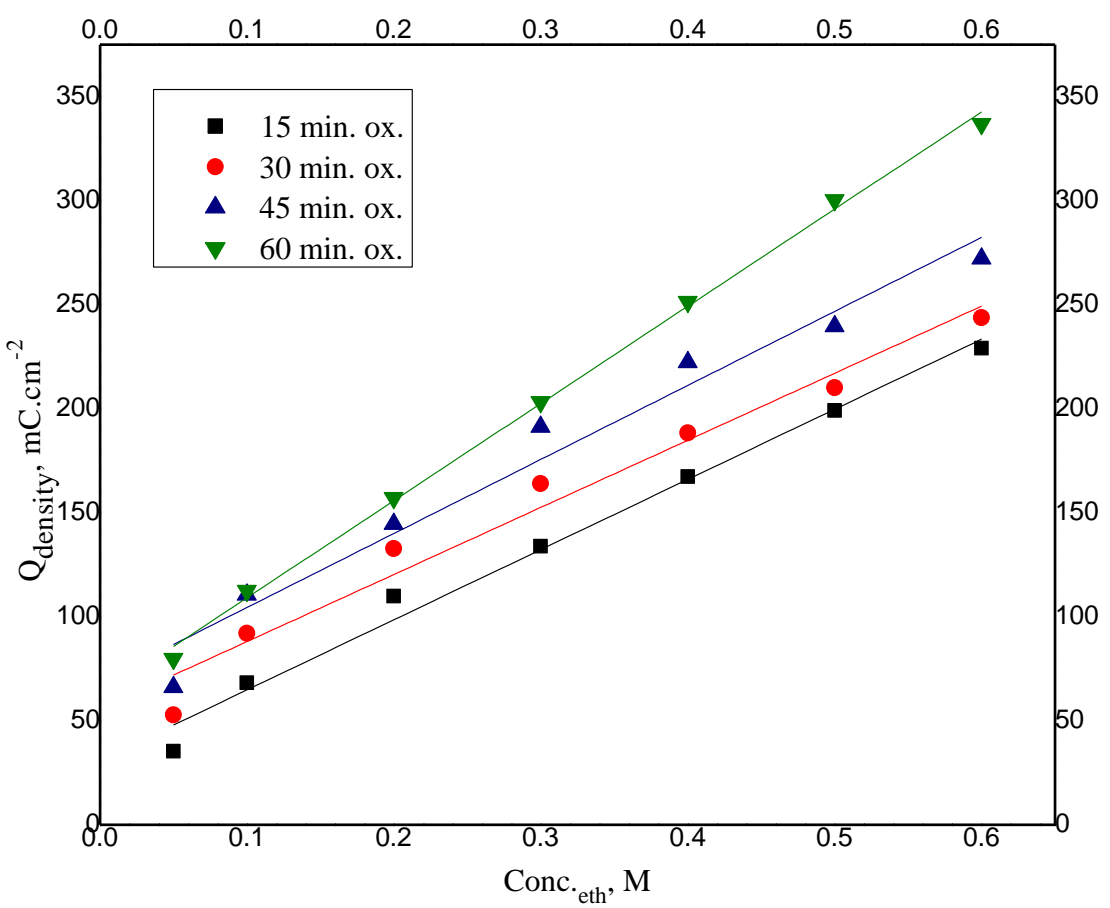

Fig. 16. Quantity of electricity as a function of ethanol concentrationin $0.1 \mathrm{M} \mathrm{HClO}_{4}$, at different times of $\mathrm{Pt}$ modification, at $25^{\circ} \mathrm{C}$.

\section{Conclusions}

In the present paper, the electrooxidation properties of ethanol which are promising candidates for DAFCs, was studied under different ethanol concentrations, temperatures and times of Pt modification with oxide formation. The electrooxidation of ethanol on modified $\mathrm{Pt}$ electrode was explored by cyclic voltammetry measurements. The major roles of Pt-O sites were to increase the activities of ethanol electrooxoidation by adsorbed water as $\mathrm{OH}_{\mathrm{ads}}$ formation on $\mathrm{Pt}$ electrode.

Modified $\mathrm{Pt}$ electrode was well characterized and utilized for the electrochemical measurement of ethanol oxidation at $10-30{ }^{\circ} \mathrm{C}$. The increase in anodic current value at higher temperatures indicated that the reaction rate would be enhanced. As a result, the current density at $25^{\circ} \mathrm{C}$ exceeds that at $10^{\circ} \mathrm{C}$ of the ethanol oxidation. At $30{ }^{\circ} \mathrm{C}$, the ethanol oxidation current density overcomes that at $25{ }^{\circ} \mathrm{C}$. The highest current density for the ethanol oxidation at $0.6 \mathrm{M}$ ethanol to peak $\mathrm{I}_{\mathrm{a}}$, is 
obtained at $30{ }^{\circ} \mathrm{C} 17.93 \mathrm{~mA} / \mathrm{cm}^{2}$, then at $25{ }^{\circ} \mathrm{C}$ is $12.31 \mathrm{~mA} / \mathrm{cm}^{2}$, whereas at $10{ }^{\circ} \mathrm{C}$ is $8.085 \mathrm{~mA} / \mathrm{cm}^{2}$. Consequently, it is deduced that ethanol has an advantage during the rising operation temperature. From the Arrhenius analysis, the activation energy of ethanol electrooxidation on the modified Pt electrode was ranged from 100.71 to 27.29 $\mathrm{kJ} \mathrm{mol}^{-1}$ for peak $\mathrm{I}_{\mathrm{a}}$. It is suggest that ethanol occur via the $\mathrm{C}-\mathrm{C}$ bond breaking pathway and lead to the lower of $E_{a}$ value.

Also, the rising of modification time for Pt electrode has a positive effect on the anode performance towards ethanol oxidation; in addition to the ethanol concentration which improved adsorption as a preceding step in ethanol oxidation.

\section{References}

[1] E. Herrero, L. J. Buller andH. D.Abruña, Chem. Rev., 101 (2001) 1897-930.

[2] C. Lamy, E. M. Belgsir, and J. M. Léger, Journal of Applied Electrochemistry, 31 (2001) 799-809.

[3] C. Lamy, A. Lima, V. Le Rhun, F. Delime, C. Coutanceau and J. M. Léger, Journal of Power Sources, 105 (2002) 283-296.

[4] J. Wang, S. Wasmus and R. F. Savinell, J. Electrochem. Soc., 142 (1995) 4218.

[5] T. D. Jarvi and E. M. Stuve, Electrocatalysis (Edited for J. Lopkowski and P.N. Ross), Chapter. 3, Wiley- VCH, New York, (1998), p. 75.

[6] L. Burke, Electrodes of Conductive Metallic Oxides (Edited for S. Trasatti), Elsevier, (1981), Chap. 3.

[7] V. Rao, C. Cremers, U. Stimming, L. Cao, S. Sun, S. Yan, G. Sun and Q. Xin, Journal of the Electrochemical Society, 154 (2007) B1138.

[8] María V. Martínez-Huerta, Nikolaos Tsiouvaras, Gonzalo García, Miguel A. Peña, Elena Pastor, José L. Rodriguez and José L. G. Fierro, Catalysts, 3 (2013) 811-838.

[9] G. A. Camara and T. Iwasita, Journal of Electroanalytical Chemistry, 578 (2005) 315.

[10] E. Antolini, J. Power Sources, 170 (2007) 1-12.

[11] T. Iwasita and W. Vielstich, Journal of Electroanalytical Chemistry and Interfacial Electrochemistry, 257:1-2 (1988) 319-324.

[12] Chi-Chang Hu, Kweun-Yo Liu, Electrochim. Acta, 44 (1999) 2727.

[13] Yi-Fu Yang and G. Denuault, J. Electroanal. Chem., 443 (1998) 273.

[14] F. Villiard and G. Jerkiewicz, Can. J. Che., 75 (1997) 1656.

[15] Riyanto, TEKNOIN, 10 (3), (2005), 181-190.

[16] D. A. Cantane, W. F. Ambrosio, M. Chatenet and F. H. B. Lima, Journal of Electroanalytical Chemistry, 681 (2012) 56-65.

[17] Hanaa B. Hassan, The Open Electrochemistry Journal, 1 (2009) 19-27.

[18] M. M. P. Janssen and J. Moolhuysen, Electrochim. Acta, 21 (1976) 869.

[19] V. S.Bagotsky, Yu. B. Vassiliev and Khazova O. A. Generalized, J. Electroanal. Chem., 81 (1977) 229-238.

[20] A. Hamnett and B. J. Kennedy, J. Electrochim. Acta, 33 (1988) 1613-1618.

[21] H. A. Gasteiger, M. N. Markovic and P. N. Ross, J. Catal. Lett., 36 (1996) 1-8.

[22] M. Schell, J. Electroanal. Chem., 457 (1998) 221.

[23] M. Krausa and W. Vielstich, J. Electroanal. Chem. 399 (1995) 7.

[24] R. S. Gonc s alves, J. M. Léger and C. Lamy, Electrochim. Acta, 34 (1998) 433. 
[25] H. Hitmi, E. M. Belgsir, J. M. Léger, C. Lamy and R. O. Lezna, Electrochimica Acta, 39 (1994) 407-415.

[26] E. Antolini, J. Power Sources, 170 (2007) 1.

[27] J. Willsau and J. Heitbaum, J. Electroanal. Chem., 194 (1985) 27.

[28] T. Iwasita and E. Pastor, Electrochim. Acta, 39 (1994) 531.

[29] B. Bittins-Cattaneo, S. Wilhelm, E. Cattaneo, H. W. Buschmann, W. Vielstich and Ber. Bunsenges, Phys. Chem., 92 (1988) 1210.

[30] J. F. E. Gootzen, W. Visscher and J. A. R. Van Veen, Langmuir, 12 (1996) 5076.

[31] F. Vigier, C. Coutanceau, A. Perrard, E. M. Belgsir and C. Lamy, Journal of Applied Electrochemistry, 34 (2004) 439-446.

[32] R. A. Rightmire, R. L. Rowland, D. L. Boos and D. L. Beals, Journal of the Electrochemical Society, 111 (1964) 242.

[33] T. Iwasita and E. Pastor, Electrochimica Acta, 39 (1994) 531-547.

[34] C. Lamy, S. Rousseau, E. M. Belgsir, C. Coutanceau and J. M. Léger, Electrochimica Acta, 49 (2004) 3901-3908.

[35] R. N. Singh, A.Singh and Anindita, Int. J. Hydrogen Energy, 34 (2009) 2052-7.

[36] M. Umeda, M. Kokubo, M. Mohaedi and I. Uchida, Electrochim. Acta, 48 (2003) 1363-74.

[37] Panadda Katikawong, Tanakorn Ratana and Waret Veerasai, J. Chem. Sci., 121(3), (2009) 329-337.

[38] H. Idriss, Platinum Metals Rev., 48 (3), (2004) 105-115.

[39] Claudia Yáñez, Claudio Gutiérrez, M. Soledad Ureta-Zañartu, Journal of Electroanalytical Chemistry, 541(2003) 39-49.

[40] S. N. Pron'kin, O. A. Petrii, G. A. Tsirlina and D. J. Schiffrin, J. Electroanal. Chem., 480 (2000) 112.

[41] Omar A. Hazzazi, Ph-D-thesis "Electrochemical studies of metal deposition and surface chirality at well-defined platinum single crystal electrodes", University of Wales, (2002) p:148 